\title{
Efektivitas Terapi Yoga Ketawa Terhadap Tingkat Distres Pada Mahasiswa Tahun Pertama Di Kota Yogyakarta
}

\author{
Annisa Warastri \\ Universitas 'Aisyiyah Yogyakarta \\ annisawarastri101@gmail.com \\ Andhita Dyorita Khoiryasdien \\ Universitas 'Aisyiyah Yogyakarta \\ dyoritaandhita@gmail.com
}

\begin{abstract}
Abstrak
Penelitian ini akan mengangkat fenomena mengenai stres yang dialami oleh mahasiswa tahun pertama di Kota Yogyakarta. Penyebab dari stres tersebut dari berbagai macam faktor diantaranya tuntutan yang berbeda dari lingkungan perguruan tinggi, jauh dari orang tua, tuntutan untuk mandiri, masalah keuangan dan lain-lain. Mahasiswa yang mengalami distres akan diberikan suatu intervensi yaitu Terapi Yoga Ketawa. Yoga Ketawa merupakan terapi gabungan antara yoga dan terapi ketawa yang diciptakan oleh seorang dokter India yang bernama Dr. Madan Kataria. Penelitian ini menggunakan metode kuasi - eksperimen. Desain yang digunakan adalah one group pre - posttest. Terapi Yoga Ketawa dilakukan sebanyak 6 kali pertemuan. Dari hasil penelitian diperoleh adanya peningkatan skor coping strategies dari pretest ke arah posttest, selain itu dari hasil uji hipotesis diperoleh angka signifikansi 0,000 yang menunjukkan bahwa Terapi Yoga Ketawa efektif untuk menurunkan tingkat distres pada subjek penelitian.
\end{abstract}

Kata Kunci: distress., terapi yoga ketawa

\section{Pendahuluan}

Masa remaja seringkali disebut dengan fase transisi, karena dalam fase ini terjadi masa peralihan dari masa kanak-kanak ke masa dewasa yang ditandai dengan perubahan fisik, sosial dan emosional. Selain itu, pada fase ini pula banyak perubahan yang terjadi pada seseorang baik dari fisik maupun dari psikisnya (Paramitasari \& Alfian, 2012). Santrok (2007) juga mengutarakan bahwa masa remaja ini sebagai periode "badai dan tekanan" atau "storm \& stres", yaitu suatu masa dimana ketegangan emosi meningkat sebagai akibat dari perubahan fisik. Kondisi demikian menyebabkan remaja seringkali mudah 
mengalami stres. Survei yang dilakukan oleh American Psychological Association (APA) pada Agustus 2013, saat ini remaja mudah mengalami stres (www.liputan6.com). Nasution (2007) mengungkapkan berbagai macam penyebab stres yang ada pada remaja diantaranya adalah tuntutan dari orang tua dan masyarakat.

Survei di lapangan menunjukan data bahwa remaja yang mengalami stres kebanyakan adalah mahasiswa tahun pertama. Salah satu penyebab munculnya stres di mahasiswa tahun pertama adalah perpindahan dari sekolah menengah ke perguruan tinggi (Mas'udah, 2014).

Dalam penelitian ini, subjek yang akan diteliti merupakan mahasiswa tahun pertama atau mahasiswa baru yang menjalani kuliah di Kota Yogyakarta. Yogyakarta yang lebih dikenal sebagai Kota Pelajar, merupakan salah satu kota tujuan bagi para remaja lulusan SMA untuk meneruskan pendidikan mereka ke tingkat yang lebih tinggi. Oleh karena itu, tidaklah heran jika Yogyakarta dihuni banyak mahasiswa yang berasal dari berbagai macam budaya. Budaya sendiri juga bisa merupakan salah satu penyebab stres bagi mahasiswa baru, dimana mereka harus mempelajari atau beradaptasi dengan aturan-aturan dari lingkungan baru yang mungkin bertolak belakang dengan budaya di tempat tinggal mereka.

Adanya perbedaan perilaku belajar di sekolah, dimana mereka dibimbing dan diajar serta diarahkan penuh oleh guru, sedangkan di perguruan tinggi mereka dituntut untuk mandiri dalam segala hal. Faktor lain yang menyebabkan stres pada mahasiswa diantaranya tinggal berjauhan dengan orang tua, pengaturan keuangan, masalah dengan teman sebaya dan lain-lain. Hal tersebut menyebabkan mahasiswa mengalami banyak tekanan dan tuntutan yang memicu terjadinya stres (Christyanti dkk, 2010). Stres yang dialami oleh mahasiswa menyebabkan adanya, penurunan minat dan efektivitas, kurang energi, cenderung mengekspresikan pandangan sinis pada orang lain, mudah marah, murah cemas, menjadi pemurung, sering mengeluh, tidak tenang, tertekan, mudah menangis, menjadi pemberontak dan lain-lain.

Lazarus (dalam Christyanti dkk, 2010) menjelaskan bahwa stres merupakan bentuk interaksi antara individu dengan lingkungan yang dinilai 
individu sebagai sesuatu yang membebani atau melampaui kemampuan yang dimiliki, serta mengancam kesejahteraan.

Kemudian menurut Lazarus (dalam Christyanti dkk, 2010) terdapat dua bentuk stres, yaitu Distres (stres negatif) merupakan stres yang mengganggu. Individu yang tidak mampu mengatasi keadaan emosinya akan mudah terserang distres. Kedua, Eustres (stres positif) yaitu stres baik atau stres yang tidak menganggu dan memberikan perasaan bersemangat. Dengan kata lain, mahasiswa baru menunjukan adanya kondisi distres.

Selain psikis, stres dapat mempengaruhi fisik seseorang, hal ini dikarenakan saat stres, tubuh memproduksi hormon stres adrenalin dan epinepherine yang sangat kurang baik untuk tubuh jika dibiarkan dalam waktu lama (Hayati dan Motingatu, 2015). Oleh karena itu, perlu dilakukan upaya pencegahan untuk meminimalisir stres yang timbul.

Stres yang dialami oleh mahasiswa baru ini harus diatasi dengan baik. Adapun cara penanganan stres biasa disebut dengan coping. Konsep umum coping adalah menangani masalah atau mengatur emosi akibat masalah sehingga meminimalisir timbulnya stres. Beberapa penelitian mengungkap berbagai macam bentuk terapi untuk menurunkan tingkat stres diantaranya Berpikir positif untuk menurunkan stres psikologis (Kholidah dan Alsa, 2012), pengaruh terapi musik klasik dan murotal terhadap penurunan tingkat stres (Ardiansyah, 2014) dan pengaruh terapi tertawa terhadap penurunan tingkat stres (Supardi, 2016).

Tubuh yang rileks terbukti mampu untuk menurunkan tingkat stres, salah satu cara untuk mencapai kondisi relaks adalah dengan cara tertawa. Berbagai macam penelitian telah menjelaskan manfaat dari terapi tawa, yaitu tertawa dapat menurunkan kadar hormon stres, jadi bisa dikatakan tertawa merupakan meditasi dinamis atau teknik relaksasi yang dinamis dalam waktu singkat (Tarigan, 2009). Tertawa juga dapat meningkatkan sistem kerja syaraf parasimpatis sehingga tubuh menjadi lebih rileks (Desinta, 2011). Sejalan dengan hal tersebut, Weinberg (2013) menyebutkan bahwa terapi tawa juga telah dikaitkan dengan sejumlah manfaat fisiologis dan psikologis seperti peningkatan mood positif serta penurunan stres. 
Berbeda dengan penelitian sebelumnya, dalam penelitian ini tingkatan distres akan diturunkan dengan metode terapi tawa yang dikombinasikan dengan gerakan yoga yang nantinya akan menghasilkan suatu terapi Yoga Ketawa.

Yoga Ketawa (Hasya Yoga) merupakan sebuah teknik yoga yang dirancang oleh seorang dokter India yang bernama Dr. Madan Kataria berdasarkan pada proporsi bahwa simulasi tawa dapat memberikan manfaat fisiologis dan psikologis yang sama dengan tawa sebenarnya (Weinberg, 2013). Woodbury dan Schwabe (2015) mengutarakan bahwa terapi yoga ketawa bertujuan untuk menghidupkan kembali suasana kegembiraan yang sering terjadi pada anak kecil, dimana anak kecil tertawa sering kali tanpa syarat.

Meskipun terapi ini sudah banyak dilakukan, namun belum banyak penelitian yang secara khusus membahas efektifitas yoga ketawa dalam menurunkan tingkat distres.

Manfaat gerakan Yoga bisa dilihat dari berbagai macam aspek, yaitu secara fisik dapat membantu proses pernapasan, menurunkan detak jantung, meningkatkan kekuatan dan keseimbangan tubuh. Kemudian secara psikologis, gerakan yoga mampu menurunkan tingkat stres, kecemasan dan depresi. Kemudian secara spiritual, mampu meningkatkan kesadaran terhadap dirinya sendiri (Kinasih, 2010)

Yoga ketawa merupakan terapi yang mudah untuk dipraktekan. Diharapkan dengan terapi Yoga Ketawa, mahasiswa baru akan lebih rileks sehingga mampu menurunkan tingkatan distres yang dialami. Tujuan dari penelitian ini adalah untuk memperoleh gambaran efektifitas Terapi Yoga Ketawa terhadap distres pada mahasiswa baru di Kota Yogyakarta.

\section{Stres}

Menurut Lazarus \& Folkman (dalam Christyanti, 2010) stres merupakan bentuk interaksi antara individu dengan lingkungan yang dinilai individu sebagai sesuatu yang membebani atau melampaui kemampuan kemampuan yang dimiliki, serta mengancam kesejahteraan.

Slamet dan Markam (dalam Christyanti, 2010) mengemukakan bahwa stres adalah suatu keadaan dimana beban yang dirasakan seseorang tidak sepadan 
dengan kemampuan untuk mengatasi beban itu.

\section{Bentuk - bentuk Stres}

Menurut Lazarus bentuk stres terdapat dua macam, diantaranya:

a. Distres (stres negatif) yaitu stres yang mengganggu. Idnividu yang tidak mampu mengatasi keadaan emosinya akan mudah terserang distres. Ciri-ciri individu yang telah mengalami distres yaitu mudah marah, cepat tersinggung, sulit berkonsentrasi, sukar mengambil keputusan, pelupa, pemurung, tidak energik dan cepat bingung.

b. Eustres (stres positif) yaitu stres baik atau stres yang tidak menganggu dan memberikan perasaan bersemangat. Stres yang bermanfaat dan konstruktif.

\section{Yoga Ketawa}

Yoga Ketawa (Hasya Yoga) merupakan sebuah teknik yoga yang dirancang oleh seorang dokter India yang bernama Dr. Madan Kataria berdasarkan pada proporsi bahwa simulasi tawa dapat memberikan manfaat fisiologis dan psikologis yang sama dengan tawa sebenarnya (Weinberg, 2013).

Dewi (2010) juga mengungkapkan sesi yang dilakukan dalam Yoga Ketawa yaitu, dimulai dalam kelompok dengan teknik pemanasan ringan seperti peregangan tubuh, tepuk tangan yang berirama sambil mengucapkan 'hoho...hahaha', pernafasan yang dalam, mengucapkan afirmasi 'very good...very goodd.., yeaaah...', dan lalu diikuti gerakan tubuh yang diikuti ketawa. Latihanlatihan ini dapat membantu membuat seseorang lebih rileks dan dapat membuat individu merasa ingin bermain seperti anak-anak. Selain itu, hal tersebut juga membuat seseorang merasa lepas dan bebas dari tekanan dan emosi-emosi negatif.

Penelitian Supardi (2016) menegaskan bahwa tertawa satu menit sebanding dengan bersepeda selama 15 menit. Hal ini tentu akan membuat tekanan darah menurun, terjadi peningkatan oksigen pada darah yang akan mempercepat penyembuhan pada luka. Tertawa juga melatih otot dada, pernapasan, wajah, kaki dan punggung.

Dewi (2010) menyebutkan bahwa dengan yoga ketawa dapat membuat seseorang lebih rileks. Sejalan dengan Dewi (2010), Woodbury and Schwabe 
(2015) juga menegaskan bahwa manfaat yoga ketawa tidak hanya disebabkan dari ikatan emosional yang terjadi saat para peserta berbagi tawa berbagi tawa, namun juga ketika peserta benar-benar ingin tertawa.

\section{Metode}

\section{Rancangan Penelitian}

Penelitian ini menggunakan metode kuasi - eksperimen. Desain yang digunakan adalah one group pre - posttest design. Desain penelitian pada penelitian ini digambarkan sebagai berikut:

Tabel 1. Desain Penelitian

\section{Keterangan:}

\begin{tabular}{|c|c|c|}
\hline Pretest & Treatment & Posttest \\
\hline $\mathrm{Y}_{1}$ & $\mathrm{X}$ & $\mathrm{Y}_{2}$ \\
\hline
\end{tabular}

$\mathbf{Y}_{1} \quad$ : Pengukuran Tingkat Distress sebelum melakukan treatment

$\mathrm{X} \quad$ : Pemberian treatment berupa Terapi Yoga Ketawa

$\mathbf{Y}_{2} \quad$ : Pengukuran Tingkat Distress setelah melakukan treatment

Dalam penelitian ini, awalnya akan dilaukan pengukuran tingkat distress subjek penelitian $\left(\mathrm{Y}_{1}\right)$ menggunakan coping strategies scale untuk melihat kondisi murni distress sebelum diberikan treatment (Pre-test). Selanjutnya, subjek akan diberikan treatment berupa terapi yoga ketawa. Setelah selesai diberikan treatment, maka akan dilakukan kembali pengukuran terhadap subjek penelitian $\left(\mathrm{Y}_{2}\right)$ untuk melihat tingkay distress setelah diberikan treatment (Posttest).

Pelaksanaan Terapi Yoga Ketawa dilakukan sebanyak enam kali pertemuan, dalam kurun waktu dua bulan selama dua jam di setiap pertemuan.

Pengukuran awal (pretest) tingkat distres mahasiswa akan dilakukan di pertemuan ke-2 sebelum terapi dilakukan. Sedangkan, untuk pengukuran akhir (posttest) tingkat distres akan dilakukan pada pertemuan ke-5 setelah terapi diberikan. Hal ini dimaksudkan agar peserta dapat memahami perbedaan yang dialami setelah melakukan yoga ketawa dan dapat mengevaluasi dirinya baik dari segi fisik, psikis, dan perilaku setelah beberapa kali melakukan yoga ketawa. Pelaksanaan Yoga Ketawa ini akan dibimbing langsung oleh trainer yoga ketawa bersertifikasi internasional. 


\section{Distres}

Secara operasional Distres adalah keadaan internal dalam diri mahasiswa yang dapat diakibatkan oleh tuntutan fisik dari tubuh atau kondisi lingkungan dan sosial yang dinilai potensial membahayakan, tidak terkendali atau melebihi kemampuan individu untuk mengatasinya.

\section{Terapi Yoga Ketawa}

Terapi ini akan diberikan mengikuti struktur standar sesi Yoga Ketawa (Weinberg, 2013), yang melibatkan pengulangan tiga komponen utama yaitu :

\section{1) Laugh Phase}

Selama fase ini, instruktur memandu peserta melalui kegiatan untuk mensimulasikan tawa. Awal sesi biasanya dimulai dengan melibatkan sapaan, dimana peserta saling menyapa dengan berjabat tangan dan tertawa sambil tetap menjaga kontak mata. Fase tertawa dapat melibatkan berbagai jenis tawa, seperti 'singa tertawa'. Buka mulut dan julurkan lidah, rentangkan tangan seperti cakaran singa dan raungan, lalu tertawa dari perut hingga merasakan peregangan pada otot wajah, lidah dan tenggorokan. Selain itu, bisa juga mempraktekan 'tawa telepon' atau 'sarapan makan tertawa' dengan gerakan menyesuaikan.

2) Clap Phase

Dalam fase 'Clap', peserta berhenti sejenak untuk mengulang kata yang khas digunakan saat Yoga Ketawa yaitu 'Ho, ho, $h a, h a, h a$ ' sambil bertepuk tangan dalam irama. Peserta dapat terus bertepuk tangan dengan irama 1-2-3, gerakkan tangan ke atas dan ke bawah dan ayunkan dari sisi ke sisi saat bertepuk tangan. Tepuk tangan dengan sejajar satu sama lain, akan merangsang titik akupresur pada tangan dan dapat meningkatkan energi.

3) Breathe Phase (Pranayama)

Dalam fase pernapasan, peserta fokus untuk bersantai dan mengatur pernapasan mereka. Peserta diminta untuk melakukan teknik pernapasan yang lambat dan berirama dengan gerakan tangan. Hal tersebut akan membantu kondisi fisik dan psikologis menjadi semakin 
rileks. Peserta diminta untuk mengambil napas sedalam mungkin, lalu serentak mengangkat kedua lengan ke arah langit saat menarik napas dan hembuskan perlahan. Tahan nafas selama 4-5 detik sambil tersenyum pada saat bersamaan.

Pengambilan subjek penelitian diambil berdasarkan metode random sampling. Dalam penelitian ini, subjek yang ingin di teliti adalah mahasiswa tahun pertama yang menampilkan gejala distres di Kota Yogyakarta. Adapun jumlah keseluruhan subjek adalah 20 orang.

Alat ukur yang digunakan dalam penelitian ini adalah skala coping strategies (Coping Strategies Scale) berdasarkan teori stres dari Lazarus (Terlampir).

Metoda pengumpulan data dalam penelitian ini mengacu pada hasil wawancara dengan beberapa mahasiswa tahun pertama di Yogyakarta. Data pendukung lain diperoleh dengan metode studi pustaka dan jurnal-jurnal ilmiah, serta literatur lain yang memuat bahasan yang berkaitan dengan penelitian ini.

Adapun metoda pengumpulan data yang digunakan dalam penelitian ini adalah:

\section{Skala Strategi Koping (Coping Strategies Scale)}

Coping Strategies Scale akan diberikan kepada subjek sebelum diberikan program terapi untuk memperoleh gambaran awal yang konsisten terhadap kecencerungan tingkat distres subjek. Kemudian, Coping Strategies Scale akan diberikan lagi setelah terapi untuk melihat perubahan tingkat distres subjek.

\section{Wawancara}

Wawancara dilakukan terhadap subjek penelitian dengan panduan wawancara sebagai berikut :

a. Pertanyaan seputar riwayat kehidupan klien selama menjalani perkuliahan, termasuk di dalamnya prestasi akademik klien dan faktor-faktor yang mendukung kegiatan belajar klien.

b. Pertanyaan yang berkaitan dengan etiologi, latar belakang keluarga, hubungan dengan orang tua, teman-teman, faktor peredisposisi, 
lingkungan / gaya hidup sehari - hari klien, tujuan hidup yang dimiliki serta usaha-usaha guna mencapai tujuan tersebut.

\section{Observasi}

Aktivitas yang diamati dari subyek penelitian selama treatment berlangsung antara lain:

a. Gejala yang nampak pada mahasiswa baru yang memiliki kecenderungan distres.

b. Respon klien selama diberikan terapi termasuk didalamnya kesulitan yang muncul pada proses terapi dan cara penanggulangannya.

Pada penelitian ini terdapat dua teknik analisa yang akan digunakan, yaitu analisa kuantitatif dan analisa kualitatif. Teknik analisis yang digunakan dalam penelitian ini adalah statistik desriptif. Data kuantitatif yang diperoleh dalam penelitian klinis merupakan serangkaian data empiris hasil pengamatan terhadap sekelompok individu yang harus diolah, dianalisa, dan disimpulkan agar berguna dalam menggambarkan perilaku. Pengolahan hasil data menggunakan program SPSS.22.

Data kualitatif akan dianalisis menurut isinya (content analysis) atau disingkat analisis isi. Data kualitatif yang dimaksud disini adalah data yang diperoleh dari wawancara, tugas-tugas yang dilakukan, maupun data yang diperoleh selama proses terapi selama tatap muka. Analisis isi ini adalah teknik yang digunakan untuk menarik kesimpulan melalui usaha menemukan karakteristik pesan, serta dilakukan secara objektif dan sistematik. Dengan analisis isi, peneliti menggunakan data yang ada untuk mengidentifikasi pola-pola yang nampak.

\section{Hasil Dan Pembahasan}

\section{Hasil}

Penelitian ini menggunakan skala coping strategies yang dikembangkan oleh Lazarus. Skala kuesioner ini berisi 67 pertanyaan dan memiliki 4 kategori jawaban yang memiliki nilai di setiap masing-masing jawaban, yaitu: 
Tabel 2 Tabel Kategori Jawaban Skala Coping Strategies

\begin{tabular}{|l|l|c|}
\hline Kategori & \multicolumn{1}{|c|}{ Deskripsi } & Nilai \\
\hline STS & Sangat Tidak Sesuai & 0 \\
\hline TS & Tidak Sesuai & 1 \\
\hline S & Sesuai & 2 \\
\hline SS & Sangat Sesuai & 3 \\
\hline
\end{tabular}

Dalam penelitian ini, proses pengumpulan data akan dimulai dari dilakukannya pengukuran terhadap tingkat distres pada subjek penelitian sebanyak satu kali sebelum diberikan terapi (Pretest $\rightarrow Y_{l}$ ) dengan menggunakan skala coping strategies. Selanjutnya subjek penelitian akan mengikuti program Terapi Yoga Ketawa. Setelah terapi selesai diberikan, selanjutnya akan dilakukan kembali pengukuran terhadap tingkat distres pada subjek penelitian sebanyak satu kali (Posttest $\rightarrow Y_{2}$ ) dengan menggunakan skala coping strategies. Pengukuran ini dilakukan untuk melihat perubahan tingkat distres subjek penelitian setelah mengikuti kegiatan terapi yang fungsinya guna membantu subjek untuk menurunkan tingkat distres yang dimiliki. Perubahan tingkat distres pada subjek penelitian dapat dilihat dari skala coping strategies dimana hasil dari skala tersebut dikategorikan melalui norma alat ukur. Jika skor yang didapat subjek semakin kecil, maka semakin rendah kemampuan mereka dalam mengatasi stres (coping strategies). Dengan kata lain, semakin tinggi tingkat distres yang mereka miliki. Akan tetapi jika skor yang didapat subjek penelitian semakin besar, maka semakin tinggi kemampuan mereka dalam mengatasi stres yang dihadapi. Dengan kata lain, semakin rendah tingkat distres yang mereka miliki.

Berikut merupakan hasil skor pretest tingkat distres subjek penelitian sebelum melakukan terapi Yoga Ketawa. Hasil data statistik dalam penelitian ini diproleh dengan memakai program SPSS.

Tabel 3. Tabel Pretest Subjek Penelitian

Descriptive Statistics

\begin{tabular}{|l|r|r|r|r|r|}
\hline & \multicolumn{1}{|c|}{ N } & Minimum & Maximum & \multicolumn{1}{l|}{ Mean } & Std. Deviation \\
\hline Pretest & 20 & 79 & 124 & 101,00 & 14,539 \\
Valid N (listwise) & 20 & & & & \\
\hline
\end{tabular}


Dari hasil tabel 3 dapat dilihat bahwa skor minimum di antara 20 subjek penelitian adalah 79 , sedangkan skor maximumnya adalah 124 . Rata-rata hasil skor pretest adalah 101 dan Standar Deviasi sebesar 14,539.

Kemudian dibawah ini akan dijelaskan hasil skor posttest tingkat distres subjek penelitian sesudah melakukan terapi Yoga Ketawa.

Tabel 4. Tabel Posttest Subjek Penelitian

Descriptive Statistics

\begin{tabular}{|l|r|r|r|r|r|}
\hline & \multicolumn{1}{|c|}{ N } & Minimum & Maximum & Mean & Std. Deviation \\
\hline Posttest & 20 & 119 & 157 & 137,70 & 11,337 \\
Valid N (listwise) & 20 & & & & \\
\hline
\end{tabular}

Dari hasil tabel 4 dapat dilihat bahwa skor minimum di antara 20 subjek penelitian adalah 119 , sedangkan skor maximumnya adalah 157 . Rata-rata hasil skor pretest adalah 137,7 dan Standar Deviasi sebesar 11,337.

Berdasarkan hasil skor pretest maupun posttest, maka terdapat peningkatan skor nilai minimum maupun maximum, sehingga hal ini mempengaruhi rata-rata nilai secara keseluruhan. Peningkatan skor ini menunjukkan bahwa setelah diberikan Terapi Yoga Ketawa maka ada peningkatan tingkat kemampuan subjek penelitian dalam mengelola stres (coping strategies), dengan meningkatnya kemampuan mereka dalam mengelola stres maka tingkat distres yang mereka miliki pun akan menurun.

Uji normalitas menggunakan rumus Uji Shapiro-Wilk menggunakan program SPSS 21.00, dikarenakan jumlah sampel yang kurang dari 30. Untuk mengetahui normal tidaknya adalah jika sig pada kolom Shapiro-Wilk $>0,05$ maka data berdistribusi normal dan jika sig $<0,05$ dapat dikatakan tidak normal. Di bawah ini akan ditampilkan hasil uji normalitas pada data penelitian.

Tabel 5. Uji Normalitas Data Penelitian

Tests of Normality

\begin{tabular}{|l|r|r|r|r|r|r|}
\hline & \multicolumn{3}{|c|}{ Kolmogorov-Smirnov $^{\text {a }}$} & \multicolumn{3}{c|}{ Shapiro-Wilk } \\
\cline { 2 - 7 } & Statistic & \multicolumn{1}{|c|}{ df } & \multicolumn{1}{c|}{ Sig. } & \multicolumn{1}{c|}{ Statistic } & \multicolumn{1}{c|}{ df } & \multicolumn{1}{c|}{ Sig. } \\
\hline Pretest &, 160 & 20 &, 192 &, 932 & 20 &, 166 \\
Posttest &, 125 & 20 &, $200^{*}$ &, 961 & 20 &, 561 \\
\hline
\end{tabular}

${ }^{*}$. This is a lower bound of the true significance.

a. Lilliefors Significance Correction 
Dari tabel 5 dapat dilihat bahwa hasil Uji Shapiro-Wilk untuk data Pretest memiliki nilai sig sebesar 0,166 dan data Posttest memiliki nilai sig sebesar 0,561. Nilai sig $>0,05$ baik data pretest maupun posttest, hal ini menunjukkan bahwa data berdistribusi normal dan dapat diuji secara parametrik.

Untuk melihat apakah Terapi Yoga Ketawa efektif untuk menurunkan tingkat distres pada subjek penelitian maka akan dilakukan uji Paired Sample $t$ Test.

Tabel 6. Uji Paired Sample t Test

Paired Samples Test

\begin{tabular}{|c|c|c|c|c|c|c|c|c|}
\hline & \multicolumn{5}{|c|}{ Paired Differences } & \multirow[b]{3}{*}{$t$} & \multirow[b]{3}{*}{$d f$} & \multirow[b]{3}{*}{ Sig. (2-tailed) } \\
\hline & \multirow[b]{2}{*}{ Mean } & \multirow[b]{2}{*}{ Std. Deviation } & \multirow{2}{*}{$\begin{array}{l}\text { Std. Error } \\
\text { Mean }\end{array}$} & \multicolumn{2}{|c|}{$\begin{array}{l}\text { 95\% Confidence Interval of the } \\
\text { Difference }\end{array}$} & & & \\
\hline & & & & Lower & Upper & & & \\
\hline Pair 1 Pretest-Posttest & $-36,700$ & 17,794 & 3,979 & $-45,028$ & $-28,372$ & $-9,224$ & 19 &, 000 \\
\hline
\end{tabular}

Hasil uji paired sample t test menunjukkan nilai sig sebesar 0,000 . Nilai sig $<0,05$ dapat disimpulkan bahwa hipotesis diterima. Dari hasil ini maka dapat disimpulkan bahwa Terapi Yoga Ketawa efektif untuk menurunkan tingkat distres pada mahasiswa tahun pertama di Yogyakarta.

\section{Pembahasan}

Penelitian ini bertujuan untuk mengetahui apakah Terapi Yoga Ketawa efektif untuk menurunkan tingkat distres pada mahasiswa tahun pertama di Yogyakarta. Hipotesis penelitian yang dinyatakan diterima menunjukkan bahwa Terapi Yoga Ketawa terbukti efektif untuk menurunkan tingkat distres pada subjek penelitian.

Mahasiswa baru mengalami stres yang disebabkan karena berbagai hal, diantaranya kesulitan mereka dalam beradaptasi dengan lingkungan baru, baik itu lingkungan kos ataupun lingkungan perguruan tinggi. Berdasarkan wawancara yang telah dilakukan, diperoleh juga fakta bahwa tuntutan dari perguruan tinggi yang mengharuskan mereka bersikap mandiri dalam berbagai hal, tinggal berjauhan dengan orang tua, pengaturan keuangan serta masalah dengan teman sebaya menyebabkan kondisi yang penuh tekanan dan tuntutan. Hal tersebut tentu memicu terjadinya stres (Christyanti, 2010). Stres yang dialami oleh mahasiswa 
menyebabkan adanya penurunan minat dan efektivitas, kurang energi, cenderung mengekspresikan pandangan sinis pada orang lain, mudah marah, murah cemas, tidak tenang, tertekan, mudah menangis, menjadi pemberontak dan lain-lain.

Beberapa penelitian sudah mengungkapkan berbagai macam intervensi untuk menurunkan tingkat stres, namun dalam penelitian ini mahasiswa baru yang mengalami stres akan diberikan terapi Yoga Ketawa. Tubuh seseorang harus rileks agar dapat menurunkan tingkat stres. Hal ini bisa tercapai dengan cara tertawa. Berbagai macam penelitian menunjukan bahwa tertawa memberikan banyak manfaat, diantaranya adalah menurunkan kadar hormon stres. Oleh karena itu, bisa dikatakan bahwa tertawa merupakan meditasi dinamis atau teknik relaksasi yang dinamis dalam waktu singkat (Tarigan, 2009). Kemudian, dengan tertawa juga dapat meningkatkan sistem kerja syaraf parasimpatis sehingga tubuh lebih rileks (Desinta, 2011). Dalam penelitian ini, tingkatan stres akan diturunkan dengan metode terapi tawa yang dikombinasikan dengan gerakan yoga yang nantinya akan menghasilkan suatu terapi Yoga Ketawa.

Manfaat gerakan Yoga bisa dilihat dari berbagai macam aspek, yaitu secara fisik dapat membantu proses pernapasan, menurunkan detak jantung, meningkatkan kekuatan dan keseimbangan tubuh. Secara psikologis, gerakan yoga mampu menurunkan tingkat stres, kecemasan dan depresi. Kemudian secara spiritual, mampu meningkatkan kesadaran terhadap dirinya sendiri (Kinasih, 2010).

Dari hasil penelitian diperoleh data bahwa terjadi peningkatan nilai kemampuan subjek penelitian dalam mengatasi stres (coping strategies) yang dimiliki oleh subjek. Hal ini bisa dilihat dari adanya peningkatan skor posttest baik skor minimum maupun maximum setelah diberikan Terapi Yoga Ketawa. Dengan meningkatnya tingkat kemampuan dalam mengatasi stres (coping strategies) yang dimiliki subjek, maka tingkat distres yang dimiliki subjek pun akan menurun. Hal ini sesuai dengan yang disampaikan oleh certified laughter yoga, Dewi (2015) bahwa yoga ketawa mempunyai banyak manfaat salah satunya sebagai stress buster dan laughter boosting untuk menghadapi suasana stres. Tertawa merupakan stress bhuster instan dan terbukti secara ilmiah bahwa tertawa 
mengurangi tingkat hormone stress seperti kortisol dan epinephrine serta meningkatkan emosi positif. Sedangkan laughter boosting dapat untuk meningkatkan endorphin dalam diri seseorang.

\section{Kesimpulan Dan Saran}

\section{Kesimpulan}

Hasil penelitian menunjukkan adanya efektifitas Terapi Yoga Ketawa untuk menurunkan tingkat distress pada mahasiswa tahun pertama di Yogyakarta. Hal ini ditunjukkan dengan peningkatan skor kemampuan dalam mengelola stres (coping strategies) pada subjek setelah diberikan Terapi Yoga Ketawa, peningkatan skor coping strategies pun menyebabkan tingkat distres yang dimiliki subjek menurun.

Kemudian dari hasil uji hipotesis didapat angka signifikansi sebesar 0,000 maka, dapat disimpulkan bahwa hipotesis penelitian yang menyatakan Terapi Yoga Ketawa efektif untuk menurunkan tingkat distres pada mahasiswa tahun pertama di Yogyakarta diterima

\section{Saran}

Berikut ini terdapat saran-saran yang terkait dengan hasil dan pembahasan penelitain, yaitu:

1. Bagi subjek penelitian, menghindari kemungkinan terjadinya peningkatan tingkat distres maka keterampilan-keterampilan yang telah dipelajari selama sesi terapi agar terus diterapkan dalam kehidupan sehari-hari

2. Kepada pihak peneliti yang tertarik membahas distres agar lebih memperhatikan faktor tipe kepribadian yang dimiliki subjek dan pola asuh yang dimiliki dari masing-masing subjek.

3. Kepada pihak peneiliti berikutnya, sebaiknya memperhatikan faktor jenis kelamin agar hasil penelitian semakin spesifik karena dibedakan antara laki-laki dan perempuan. 


\section{DAFTAR PUSTAKA}

Ardiansyah, G. 2014. Pengaruh Terapi Musik Klasik dan Murotal Terhadap Penurunan Tingkat Stres Mahasiswa Semester Akhir Universitas Muhammadiyah Surakarta. Skripsi. (tidak diterbitkan). Surakarta :Universitas Muhammadiyah Surakarta.

Christyanti, D., Mustami'ah, D., Sulistiani, W. 2010. Hubungan Antara Penyesuaian Diri Terhadap Tuntutan Akademik Dengan Kecenderungan Stres Pada Mahasiswa Fakultas Kedokteran Universitas Hang Tuah Surabaya. Jurnal Insan. Vol.12, No. 3, Hal 153-159.

Desinta, S.2011. Terapi Tawa Untuk Menurunkan Stres Pada Penderita Hipertensi. Tesis. (tidak diterbitkan). Yogyakarta :Universitas Gadjah Mada.

Dewi,E.L.2010.Apa Sih Yoga Ketawa Itu.Diunduh pada 31 Mei 2017, dari http://www.pembelajar.com/apa-sih-yoga-ketawa-itu.

Dewi, E.L. 2015. Buku Panduan Certified Laughter Yoga Leader Training (Edisi Bahasa Indonesia). Yogyakarta : Laughter Yoga International University.

Hayati, R., Widyana, R., Sholichah, M. (2015). Terapi Tawa Untuk Menurunkan Kecenderungan Burnout Pada Guru Pendamping Anak Berkebutuhan Khusus. Jurnal Psikologi Indonesia Humanitas. Vol.12, No.1, Hal 60-72.

Kholidah, E. N., Alsa, A.2012. Berpikir Positif Untuk Menurunkan Stres Psikologis. Jurnal Psikologi. Vol.39, No.1, Hal 67-75.

Kinasih, A.S.2010.Pengaruh Latihan Yoga Terhadap Peningkatan Kualitas Hidup. Buletin Psikologi. Vol.18, No. 1, Hal 1-12.

Kusmiyati. 2014. Studi: Remaja Sekarang Lebih Mudah Stres. Diunduh pada 31 Mei 2017 dari http://health.liputan6.com/read/829675/studi-remajasekarang-lebih-mudah-stres.

Lazarus, R. S., Folkman, S. (1984). Stres, Appraisal and Coping. Diunduhpada 31 Mei 2017, dari http://gen.lib.rus.ec/search.php?req=richard $+\mathrm{s}+$ lazarus\&open $=0 \&$ res $=25 \&$ view $=$ simple $\&$ phrase $=1 \&$ column $=$ def.

Mas'udah, R. 2014. Hubungan Antara Strategi Coping (Koping) Stres Dengan Bentuk Stres Mahasiswa Baru Fakultas Psikologi Universitas Islam Negeri Maulana Malik Ibrahim Malang. Skripsi. (tidak diterbitkan). Malang :Universitas Islam Negeri Maulana Malik Ibrahim Malang.

Nasution, I,K. 2007. Stres Pada Remaja. Makalah Penelitian. (tidak diterbitkan). 
Medan :Universitas Sumatera Utara.

Paramitasari, R, Alfian, I.R. 2012. Hubungan Antara Kematangan Emosi Dengan Kecenderungan Memaafkan Pada Remaja Akhir. Jurnal Psikologi Pendidikan dan Perkembangan Vol 1 No 2, Juni 2012

Santrock, J.W. 2007. Adolescence : Perkembangan Remaja. Jakarta : Erlangga

Supardi. (2016). Pengaruh Terapi Tawa Terhadap Penurunan Tingkat Stres Dalam Menyusun Skripsi Pada Mahasiswa Fisioterapi Semester Akhir Di Universitas 'Aisyiyah Yogyakarta. Skripsi. (tidak diterbitkan). Yogyakarta :Universitas 'Aisyiyah Yogyakarta

Tarigan, I. 2009. Sehat Dengan Terapi Tertawa. Diunduhpada 31 Mei 2017, dari http://www.mediaindonesia.com/mediahidupsehat/index.php/read/2009/06 /25/1325/13/Sehat-dengan-Terapi-Tertawa.

Weinberg, M. K., Hammond, T. G., Cummins, R. A. (2013). A pilot Study: The Impact of Laughter Yoga on Dubjective Well-Being. Europian Journal of Humour Research 1(4), Page 25-34.

Woodbury, M. A., Schwabe, M. M. R. (2015). Laughter Yoga: Benefits of Mixing Laughter and Yoga. J Yoga Phys Ther. Vol.5, Issue 4. 